\title{
ANALISIS HUBUNGAN MEDIA SOSIAL DAN MEDIA MASSA DALAM PENYEBARAN BERITA HOAKS BERDASARKAN STRUCTURAL EQUATION MODELING-PARTIAL LEAST SQUARE
}

\author{
Christopher Andreas ${ }^{1}$, Sakinah Priandi², Antonio Nikolas Manuel Bonar \\ Simamora $^{3}$, M. Fariz Fadillah Mardianto*4 \\ ${ }^{1,2,3,4}$ Program Studi Statistika, Departemen Matematika, Fakultas Sains dan \\ Teknologi, Universitas Airlangga, Surabaya, Indonesia \\ christopher.andreas-2018@fst.unair.ac.id ${ }^{1}$, sakinah.priandi- \\ 2018@ fst.unair.ac.id ${ }^{2}$,antonio.nikolas.manuel-2019@ fst.unair.ac.id ${ }^{3}$, \\ m.fariz.fadillah.m@fst.unair.ac.id $*^{4}$ \\ *Corresponding Author
}

Received 27 June 2021; revised 12 July 2021; accepted 16 July 2021.

\begin{abstract}
ABSTRAK
Kebebasan pers adalah salah satu fokus yang terus diwujudkan dalam Sustainable Development Goals (SDGs). Dengan didukung era digital, kebebasan pers telah menciptakan keterbukaan dan penyebaran informasi yang cepat dan luas. Namun, hal tersebut diikuti dengan perkembangan berita hoaks di media sosial dan media massa yang terus tumbuh dan menjadi masalah serius di Indonesia. Perkembangan tersebut membuat analisis hubungan media sosial dan media massa dalam penyebaran berita hoaks di Indonesia penting dilakukan. Penelitian ini bertujuan untuk membentuk model struktural yang menjelaskan hubungan kedua media tersebut dalam penyebaran berita hoaks. Variabel yang digunakan dalam penelitian ini adalah perkembangan berita hoaks di media sosial dan media massa yang dianalisis dengan mempertimbangkan dua model struktural menggunakan metode Structural Equation ModelingPartial Least Square (SEM-PLS). Hasil penelitian menunjukkan bahwa perkembangan berita hoaks di media sosial dan media massa saling berpengaruh signifikan. Melalui penelitian ini, rekomendasi kebijakan terkait upaya menekan perkembangan berita hoaks di media sosial dan media massa berbasis hasil pemodelan SEM-PLS dapat dirumuskan sehingga perkembangan berita hoaks dapat diminimalisir.
\end{abstract}

Kata kunci: berita hoaks, media massa, media sosial, SEM-PLS, SDGs. 


\title{
Christopher Andreas, Sakinah Priandi, Antonio Nikolas Manuel Bonar Simamora, M. Fariz Fadillah Mardianto
}

\begin{abstract}
Press freedom is one of the focuses that continues to be realized in the Sustainable Development Goals (SDGs). Supported by the digital era, press freedom has created openness and rapid and widespread information. However, this was followed by the development of the hoax news on social media and mass media, which continued to grow and became a serious problem in Indonesia. These developments make it important to analyze the relationship between social media and mass media in spreading hoax news in Indonesia. This study aims to form a structural model that explains the relationship between the two media in the spread of hoax news.The variables used in this study were the development of the hoax news in social media and mass media, which were analyzed by considering two structural models using the Structural Equation ModelingPartial Least Square (SEM-PLS) method. The results showed that the development of hoax news in social media and mass media had a significant effect on each other.a. Through this research, policy recommendations related to efforts to suppress the development of the hoax news in social media and mass media based on the results of SEM-PLS modeling can be formulated so that the development of the hoax news can be minimized.
\end{abstract}

Keywords: hoax news, mass media, social media, SEM-PLS, SDGs.

\section{PENDAHULUAN}

Di era digital, tingginya mobilitas teknologi informasi dalam konteks media pers menyebabkan hilangnya batasan antara komunikator (penyampai pesan) dan komunikan (penerima pesan) baik dalam batasan ruang maupun waktu. Hilangnya batasan tersebut menyebabkan tingginya output informasi yang lebih beragam. Dalam hitungan detik, berbagai informasi dapat disebarkan ke seluruh dunia melalui berbagai sarana atau platform media sosial, tak terkecuali dengan berita palsu atau hoaks. Kehadiran media sosial telah menjadi ruang baru bagi masyarakat yang tidak lagi dibatasi oleh ruang dan waktu. Hilangnya batas fisik dan berkembangnya berita hoaks merupakan konsekuensi baru bagi masyarakat dunia dan telah menjadi budaya konsumtif global (Agustina, 2018). Perkembangan berita hoaks tersebut telah menimbulkan kekhawatiran dan menjadi masalah serius di berbagai negara, tak terkecuali di Indonesia (The Asean Post, 2019). Bagaimanapun, untuk mewujudkan Sustainable Development Goals (SDGs), khususnya pada pilar ke-16 yaitu penguatan masyarakat yang inklusif dan damai untuk pembangunan berkelanjutan, berita hoaks harus diminimalisir. 
Masyarakat Telematika Indonesia (Mastel) menunjukkan bahwa 89,2\% masyarakat di Indonesia terganggu dengan adanya berita hoaks dan 20,3\% masyarakat menyatakan ragu dalam membedakan apakah sebuah berita termasuk benar atau palsu. Selain itu, intensitas waktu masyarakat dalam menerima berita hoaks menunjukkan bahwa 14,7\% masyarakat menerima berita hoaks lebih dari satu kali per hari dan 34,6\% masyarakat menyatakan menerima berita hoaks setiap hari (Mastel, 2019). Data statistik hoaks yang dirilis oleh Kementerian Komunikasi dan Informatika (Kominfo) menunjukkan bahwa isu hoaks di Indonesia semakin meningkat sejak masa pandemi COVID-19 (Kominfo, 2020).

Berita hoaks di Indonesia berkembang melalui berbagai media diantaranya media massa yang meliputi media cetak, media elektronik, dan media online. Survei yang dilakukan oleh Mastel pada tanggal 1 - 15 Maret 2019 yang melibatkan 941 responden menunjukkan bahwa sebagian besar responden sering menemukan informasi hoaks melalui sosial media (87,5\%), aplikasi chatting $(67 \%)$, situs web $(28,2 \%)$, media cetak $(6,4 \%)$, dan televisi atau radio $(8,1 \%)$ (Mastel, 2019). Selain itu, Badan Intelijen Negara (BIN) menemukan bahwa $60 \%$ konten media sosial adalah informasi hoaks (Monavita, 2018).

Pada dasarnya terdapat hubungan dua arah antara penyebaran informasi di media massa dan media sosial. Dengan kata lain, informasi yang disebarkan melalui media sosial merupakan informasi yang disebarkan melalui media massa, begitupun sebaliknya (Azman, 2018). Berdasarkan data Kominfo pada periode 23 Januari - 10 Agustus 2020 menunjukkan jumlah isu hoaks paling banyak ditemukan di Facebook sebanyak 1.403 konten, disusul dengan Twitter sebanyak 478 konten, Instagram dan YouTube masing-masing sebanyak 20 konten (Kominfo, 2020). Data Kominfo (2020) juga menunjukkan bahwa 84,76\% masyarakat Indonesia mengandalkan Whatsapp untuk komunikasi sehari - hari. Sebagaimana dalam media sosial, pesan hoaks yang viral di Whatsapp seringkali berbentuk teks atau gambar yang menyebar dari satu pengguna ke pengguna lain. Selain itu, rendahnya kualitas jurnalis dan kurangnya verifikasi pada proses produksi pemberitaan pada media massa juga dapat menyebabkan konten hoaks terus berkembang (Fadli, 2018). Asiati dan Septadiyanto (2018) menyatakan bahwa Indonesia merupakan salah satu negara dengan jumlah pengguna 
Whatsapp, Facebook, dan Instagram terbesar secara keseluruhan. Hal ini menunjukkan bahwa perkembangan berita hoaks di media sosial dan media massa merupakan masalah serius yang saat ini terjadi di Indonesia.

Penelitian terkait perkembangan berita hoaks di Indonesia telah beberapa kali dilakukan. Menurut Rosmalinda (2017) menyatakan bahwa faktor penyebab penyebaran berita hoaks adalah kurangnya minat membaca, sehingga ada kecenderungan membahas berita yang tidak berdasarkan data akurat sehingga hanya mengandalkan daya ingat atau sumber yang tidak jelas. Selain itu, kemajuan dan ragam media komunikasi yang dimiliki oleh masyarakat menyebabkan masyarakat dan negara menghadapi efek hoaks sebagai akibat communication jammed yang terjadi di masyarakat (Bungin, 2017). Masyarakat sekitar juga memiliki pengaruh sebesar $6,5 \%$ terhadap intensitas berbagi informasi (Putri, 2019). Namun, penelitian tersebut belum menganalisis secara khusus bagaimana hubungan media sosial dan media massa terhadap perkembangan berita hoaks di Indonesia.

Pada penelitian ini, hubungan perkembangan berita hoaks di media sosial dan media massa dikonfirmasi dengan analisis dari berbagai indikator jenis media dengan metode Structural Equation Modeling - Partial Least Square (SEM-PLS). SEM-PLS merupakan suatu teknik analisis multivariat yang dapat digunakan untuk menguji dan mengestimasi secara simultan hubungan antara satu atau lebih variabel dependen dengan banyak faktor (Wang, et. al., 2020). Ada berbagai penelitian yang menerapkan metode SEM-PLS dalam menganalisis sebuah permasalahan seperti analisis motivasi belajar siswa pada lembaga bimbingan belajar (Mardianto, et. al., 2019). Penerapan terbaru SEM-PLS adalah untuk menganalisis kepercayaan depositor pada bank konvensional dan bank syariah di Indonesia (Cahyono, et. al., 2021), dan digunakan untuk mengetahui faktor faktor yang mempengruhi kepatuhan masyarakat Madura terhadap protokol kesehatan selama pandemi COVID-19 (Mardianto, et. al., 2021).

Analisis hubungan media sosial dan media massa dalam penyebaran perkembangan berita hoaks di Indonesia yang ditinjau dari beberapa indikator menjadi kebaharuan penelitian ini. Selain itu, penelitian ini juga berfokus pada karakteristik perilaku masyarakat dalam menyikapi perkembangan berita hoaks di 
Indonesia khususnya melalui media sosial dan media massa. Melalui penelitian ini, model statistik yang menjelaskan hubungan antar variabel dan tinjauan pustaka terkait karakteristik perilaku masyarakat dalam menyikapi perkembangan hoaks di media sosial dan media massa dapat diketahui sehingga dapat dirumuskan tindakan preventif agar masyarakat tidak mudah terkena berita hoaks. Hal dapat digunakan sebagai acuan dan rekomendasi bagi pemerintah beserta pihak terkait dalam pembuatan kebijakan, solusi, dan jalan keluar bagi masalah tersebut.

\section{METODE PENELITIAN}

Data dalam penelitian ini adalah data primer yang diperoleh melalui survei dimana respondennya telah mewakili 34 provinsi di Indonesia. Sebanyak 300 responden berpartisipasi dalam survei yang berlangsung secara luring maupun daring pada akhir Mei hingga awal Juni 2021. Persebaran responden di setiap provinsi disajikan dalam Gambar 1.

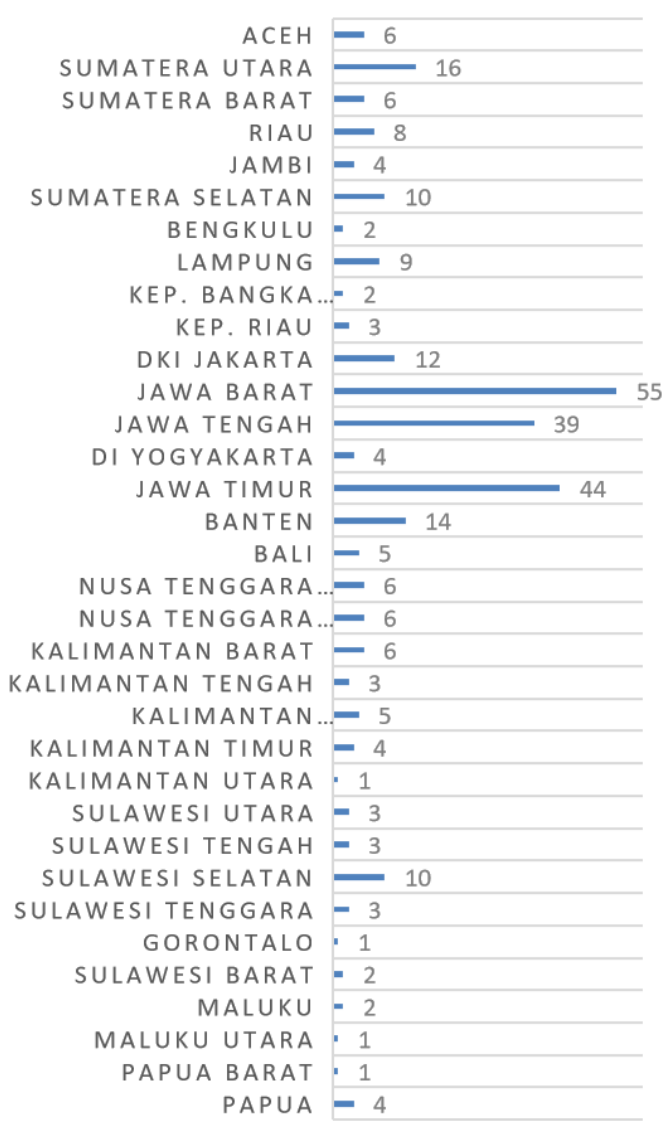

Gambar 1. Sebaran Responden Survei 
Survei dilaksanakan dengan cara menyebarkan kuesioner kepada responden yang berdomisili di Surabaya dan sekitarnya (wilayah yang mudah dijangkau), melakukan wawancara secara daring melalui video conference kepada responden yang tinggal di luar pulau, serta mendistribusikan kuesioner secara daring kepada responden dengan menggunakan Google Forms. Pertanyaan yang ditanyakan adalah mengenai perkembangan berita hoaks di media sosial dan media massa.

Teknik sampling yang digunakan untuk memperoleh sampel adalah quota sampling. Menurut Thompson (2012), quota sampling merupakan metode nonprobability sampling yang dipakai untuk memperoleh sampel berdasarkan proporsi dari distribusi suatu variabel dalam populasi. Hair, et. al., (2017) menyatakan bahwa ukuran sampel minimal yang ideal adalah sepuluh kali jumlah indikator, atau $10 \times 20$. Banyak indikator dalam penelitian ini adalah 7. Dengan demikian, ukuran sampel minimal yang sesuai dengan kaidah SEM-PLS adalah 70. Artinya, jumlah responden yang diperoleh telah memenuhi syarat.

Tabel 1. Variabel Laten terkait Berita Hoaks beserta Indikatornya

\begin{tabular}{|c|c|c|}
\hline No & Variabel & Indikator \\
\hline \multirow[t]{5}{*}{1.} & Perkembangan & Perkembangan berita hoaks di media sosial \\
\hline & Berita Hoaks di & Whatsapp $\left(S_{1}\right)$ \\
\hline & Media Sosial $(S)$ & $\begin{array}{l}\text { Perkembangan berita hoaks di media sosial Facebook } \\
\left(S_{2}\right)\end{array}$ \\
\hline & & Perkembangan berita hoaks di media soaial \\
\hline & & Instagram $\left(S_{3}\right)$ \\
\hline \multirow[t]{4}{*}{2.} & $\begin{array}{l}\text { Perkembangan } \\
\text { Berita Hoaks di }\end{array}$ & $\begin{array}{l}\text { Perkembangan berita hoaks di media cetak koran } \\
\left(M_{1}\right)\end{array}$ \\
\hline & $\begin{array}{l}\text { Media Massa } \\
(M)\end{array}$ & $\begin{array}{l}\text { Perkembangan berita hoaks di media elektronik } \\
\text { televisi }\left(M_{2}\right)\end{array}$ \\
\hline & & $\begin{array}{l}\text { Perkembangan berita hoaks di media elektronik radio } \\
\left(M_{3}\right)\end{array}$ \\
\hline & & $\begin{array}{l}\text { Perkembangan berita hoaks di media online seperti } \\
\text { website atau blog }\left(M_{4}\right)\end{array}$ \\
\hline
\end{tabular}


Data penelitian diolah dan dianalisis menggunakan metode SEM-PLS. Metode SEM-PLS melibatkan variabel laten yang tidak dapat diobservasi secara langsung namun dapat diukur oleh beberapa indikator (variabel manifes) yang berkaitan. Sebuah indikator hanya boleh berkaitan dengan satu variabel laten saja (Avkiran dan Ringle, 2018). Dalam hal ini, variabel laten dengan data ordinal yang digunakan dalam SEM-PLS ditampilkan dalam Tabel 1.

Selanjutnya, prosedur analisis diawali dengan menyusul model struktural berdasarkan kajian teori yang relevan. Model tersebut diestimasi dengan SEMPLS melalui sejumlah tahapan evaluasi model. Setelah model memenuhi seluruh kriteria dalam SEM-PLS, interpretasi dan rekomendasi dapat dirumuskan berbasis model struktural yang diperoleh.

Secara lengkap, prosedur analisis tersebut dapat dituliskan sebagai berikut.

1. Mendapatkan model berbasis konsep dan teori untuk menyusun rancangan model struktural.

2. Menghubungkan antar variabel melalui diagram jalur.

3. Mengkonversi diagram jalur ke dalam sistem persamaan struktural untuk dilakukan estimasi parameter.

Estimasi parameter model meliputi tiga hal, yaitu estimasi bobot (weight estimate), estimasi jalur (path estimate), dan estimasi rata-rata (mean) dan parameter lokasi (nilai konstanta regresi) (Ghozali, 2014).

4. Melakukan evaluasi pada outer model

Evaluasi model dilakukan pengujian validitas dan reliabilitas. Pengujian validitas dilakukan dengan melihat nilai loading factor dan Average Variance Extracted (AVE) (Ghozali, 2014).

a. Loading factor. Nilai loading factor diatas 0,7 dapat dikatakan ideal.

b. Average Variance Extracted (AVE). Nilai AVE minimal 0,5 untuk menunjukkan convergent validity yang baik.

Sedangkan pengujian reliabilitas dilakukan dengan melihat nilai composite reliability dan Cronbach's alpha

i. Composite reliability. Aturan nilai composite reliability harus lebih besar dari 0,7, meskipun 0,6 dapat diterima (Santosa, 2018). 
ii. Cronbach's alpha. Nilai cronbach's alpha harus lebih besar dari 0,7. Meskipun 0,6 masih dapat diterima (Ghozali, 2014).

5. Melakukan evaluasi pada inner model (model struktural)

Evaluasi model struktural dilakukan dengan melihat $R$-Square. Model struktural dapat dievaluasi dengan mengamati signifikansi hubungan antara variabel laten. Hal ini dapat dilihat dari path coefficient yang menggambarkan hubungan antara variabel laten. Hasil tersebut dapat diperoleh dari signifikansi path coefficient yang diperoleh dari proses bootstrapping.

6. Melakukan evaluasi pada keseluruhan model

Secara keseluruhan, model SEM-PLS dievaluasi berdasarkan nilai Indeks Goodness of Fit (GoF). Perhitungan indeks GoF dapat dilakukan dengan formulasi akar $\overline{c o m}$ dikalikan akar $\overline{R^{2}}$. Nilai $\overline{c o m}$ diperoleh rata-rata dari AVE dan $\overline{R^{2}}$ adalah nilai rata-rata dari $R$-Square dengan kriteria 0,1 (GoF small), 0,25 (GoF moderat), dan 0,36 (GoF large) (Hair, et. al., 2017).

7. Menginterpretasikan hasil permodelan.

8. Menentukan rekomendasi berdasarkan hasil model struktural.

\section{HASIL PENELITIAN DAN PEMBAHASAN}

Tahap analisis diawali dengan melakukan analisis deskriptif untuk mengetahui karakteristik responden dalam menjelaskan gambaran umum tentang variabel yang diduga berpengaruh terhadap perkembangan berita hoaks di Indonesia. Secara ringkas, demografi responden yang berasal dari berbagai kalangan masyarakat adalah 80,3\% didominasi oleh generasi milenial, 45,67\% tinggal di Pulau Jawa, 69\% berpendidikan terakhir SMA sederajat, 72,33\% sebagai mahasiswa, dan $51,33 \%$ responden memiliki waktu rata - rata harian mengkonsumsi berita antara 15 sampai 45 menit. Sebaran demografi responden tersebut logis mengingat pengakses utama media sosial dan media massa adalah generasi milenial. Menurut responden, konten berita yang kerap kali dijadikan sebagai berita hoaks secara berurutan adalah berita politik, kesehatan, ekonomi, pendidikan, entertainment, sosial, hukum, lingkungan, dan agama yang disajikan dalam Gambar 2. 


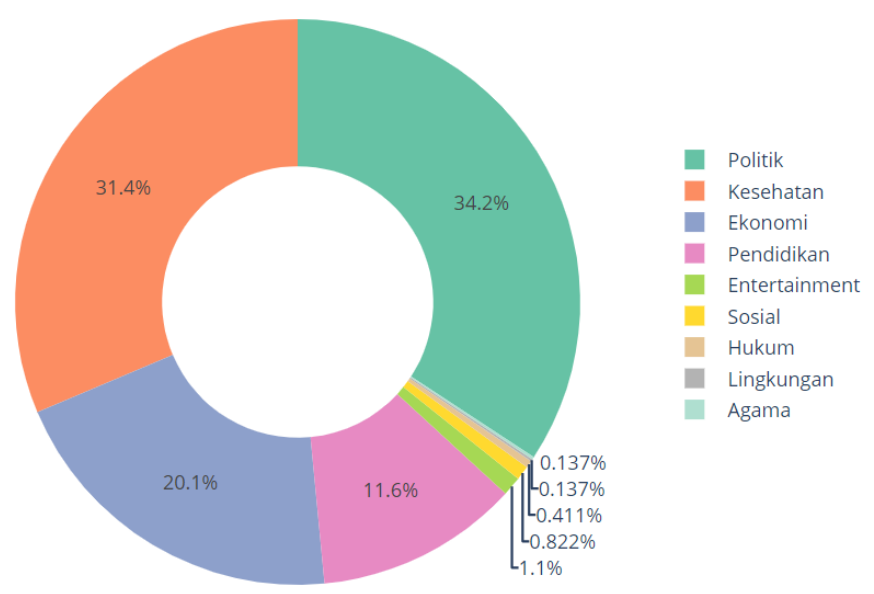

Gambar 2. Donut Chart Konten Berita Hoaks yang Sering Dijumpai Responden

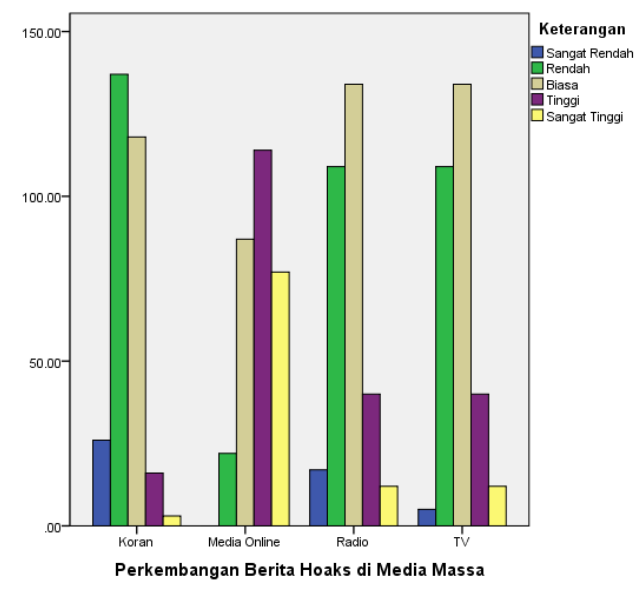

(a)

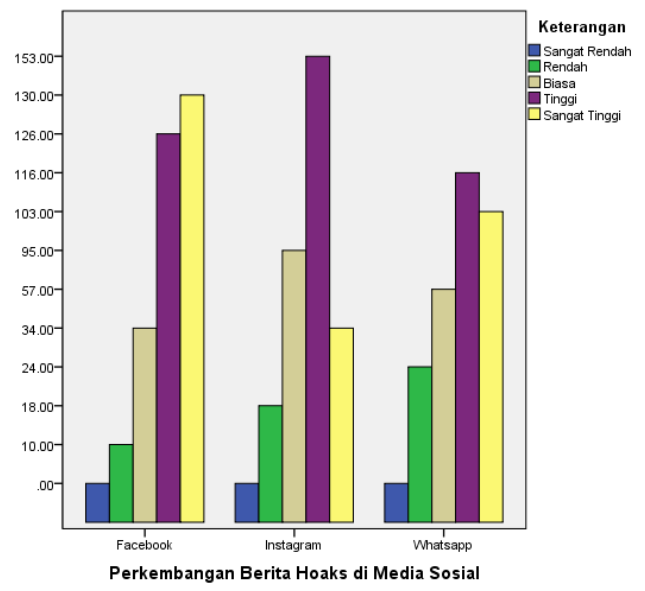

(b)

Gambar 3. Perkembangan Berita Hoaks di (a) Media Massa dan (b) Media Sosial berdasarkan Responden

Sebanyak 72,94\% responden sering mendapati adanya berita hoaks di media sosial. Tanggapan responden terkait perkembangan berita hoaks di media sosial Gambar 3. Berdasarkan Gambar 3, secara umum dapat disimpulkan bahwa mayoritas responden menyatakan bahwa perkembangan hoaks di Facebook, Instagram, dan Whatsapp tergolong tinggi. Sementara itu, responden yang sering menemui adanya berita hoaks di media massa memiliki persentase sebesar 27,06\%. Tanggapan responden terkait perkembangan berita hoaks di media sosial juga disajikan pada Gambar 3. Berdasarkan Gambar 3, secara umum dapat disimpulkan bahwa mayoritas responden menyatakan bahwa perkembangan hoaks 


\section{Christopher Andreas, Sakinah Priandi, Antonio Nikolas Manuel Bonar Simamora, M. Fariz Fadillah Mardianto}

di koran serta radio rendah, perkembangan berita hoaks di televisi tergolong biasa, dan perkembangan hoaks di media online tergolong tinggi.

Perkembangan berita hoaks di Indonesia tersebar baik melalui media sosial maupun media massa. Oleh karena itu, pemodelan SEM-PLS didasarkan pada dua model yaitu model perkembangan berita hoaks di media sosial dan model perkembangan berita hoaks di media massa. Kedua model tersebut memiliki variabel dan indikator yang sama, namun memiliki arah jalur yang berbeda seperti disajikan pada Gambar 4. Pemodelan SEM-PLS diawali dengan melakukan pengujian validitas pada setiap indikator yang digunakan. Hasil pengujian validitas pada setiap indikator tersebut ditinjau dari nilai outer loading pada setiap indikator yang disajikan pada Tabel 2 .

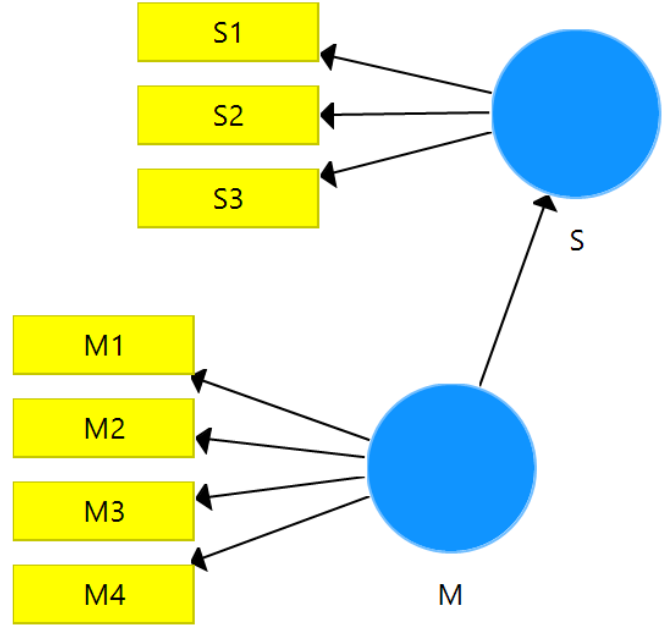

(a)

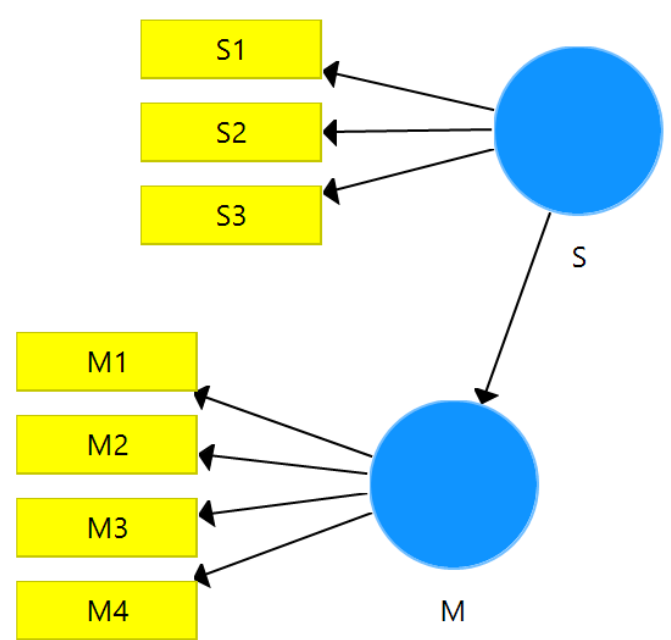

(b)

Gambar 4. Model Struktural untuk Perkembangan Berita Hoaks di (a) Media Massa dan (b) Media Sosial

Berdasarkan Tabel 2, terlihat bahwa indikator $M_{1}, M_{2}, M_{3}$, dan $S_{3}$ tidak valid yang ditandai dengan nilai outer loading yang kurang dari 0,7. Dengan demikian, variabel perkembangan berita hoaks di media massa dan sosial berturut - turut memiliki satu indikator valid dan dua indikator valid. Oleh karena itu, dilakukan estimasi ulang pada model struktural menggunakan seluruh indikator yang valid. Hasil estimasi ulang tersebut menunjukkan bahwa indikator yang 
digunakan pada setiap variabel telah valid dengan nilai outer loading yang lebih dari 0,7 seperti yang disajikan pada Tabel 2.

Tabel 2. Nilai Outer Loading pada Hasil Estimasi Awal dan Hasil Estimasi Ulang

\begin{tabular}{ccc}
\hline Indikator & $\begin{array}{c}\text { Nilai Outer Loading Estimasi } \\
\text { Awal }\end{array}$ & $\begin{array}{c}\text { Nilai Outer Loading } \\
\text { Estimasi Ulang }\end{array}$ \\
\hline$M_{1}$ & $-0,077$ & - \\
$M_{2}$ & 0,104 & - \\
$M_{3}$ & 0,078 & - \\
$M_{4}$ & 0,989 & 1,000 \\
$S_{1}$ & 0,834 & 0,841 \\
$S_{2}$ & 0,845 & 0,863 \\
$S_{3}$ & 0,459 & - \\
\hline
\end{tabular}

Selanjutnya, dilakukan evaluasi model SEM-PLS yang ditinjau dari outer model dan inner model. Dalam hal ini, evaluasi pada outer model meliputi pengujian validitas melalui uji discriminant validity yang ditinjau dari nilai cross loading dan nilai AVE, serta pengujian reliabilitas melalui kriteria composite reliability. Selain itu, dihasilkan nilai cross loading setiap indikator pada variabel laten itu sendiri yang memiliki nilai lebih besar dibandingkan dengan nilai cross loading pada variabel lain. Hal ini menunjukkan bahwa setiap indikator telah memenuhi discriminant validity. Lebih lanjut, nilai AVE dari setiap variabel menunjukkan bahwa seluruh variabel laten telah valid untuk digunakan. Hal tersebut ditandai dengan nilai $\mathrm{AVE} \geq 0,5$ seperti yang disajikan pada Tabel 3 . Selain itu, seluruh variabel juga memiliki tingkat reliabilitas yang baik dengan nilai composite reliability $>0,7$ untuk setiap variabel.

Tahap selanjutnya adalah melakukan pengujian hipotesis untuk melihat signifikansi hubungan antar variabel laten sebagai bagian dari evaluasi pada inner model. Hubungan antar variabel laten didasarkan pada model struktural seperti pada Gambar 5. Dengan proses bootstrapping, nilai koefisien jalur dan statistik T untuk setiap model struktural yang dibangun disajikan pada Tabel 4. 
Christopher Andreas, Sakinah Priandi, Antonio Nikolas Manuel Bonar Simamora, M. Fariz Fadillah Mardianto

Tabel 3. Nilai AVE dan Composite Reliability Model Struktural

\begin{tabular}{ccc}
\hline Indikator & $\begin{array}{c}\text { Perkembangan Berita } \\
\text { Hoaks di Media Sosial }\end{array}$ & $\begin{array}{c}\text { Perkembangan Berita } \\
\text { Hoaks di Media Massa }\end{array}$ \\
\hline AVE & 0,726 & 1,000 \\
Composite Reliability & 0,841 & 1,000 \\
\hline
\end{tabular}

Tabel 4. Nilai Koefisien Jalur dan Statistik T untuk Setiap Model Struktural

\begin{tabular}{ccccc}
\hline Model & Variabel & $\begin{array}{c}\text { Original } \\
\text { Sample }\end{array}$ & Statistik T & P-Value \\
\hline Perkembangan Berita & Media Massa $\rightarrow$ & 0,374 & 6,645 & 0,000 \\
Hoaks di Media Sosial & Media Sosial & & & \\
Perkembangan Berita & Media Sosial $\rightarrow$ & 0,374 & 6,868 & 0,000 \\
Hoaks di Media Massa & Media Massa & & & \\
\hline
\end{tabular}

Berdasarkan hasil pengujian pada Tabel 4, diperoleh bahwa perkembangan berita hoaks di media massa berpengaruh signifikan terhadap perkembangan berita hoaks di media sosial yang ditandai dengan nilai $p$-value sebesar 0,000 . Hal yang sama juga berlaku pada perkembangan berita hoaks di media massa yang dipengaruhi oleh perkembangan berita hoaks di media sosial. Lebih lanjut, kedua model tersebut memiliki nilai GoF yang sama yaitu sebesar 0,3476. Menurut Hair, et. al. (2017), nilai GoF masuk dalam kategori tinggi apabila mendekati nilai 0,36. Oleh karena itu, kedua model tersebut memiliki kemampuan yang tinggi dalam menjelaskan data empiris. Hasil pemodelan SEM-PLS tersebut disajikan pada Gambar 5. Bentuk akhir model SEM-PLS tersebut secara matematis dapat dituliskan sebagai berikut.

$$
\begin{aligned}
& s=0,374 m+\zeta \\
& m=0,374 s+\zeta
\end{aligned}
$$

Berdasarkan Persamaan (1), terlihat bahwa peningkatan perkembangan berita hoaks di media massa akan menyebabkan perkembangan berita hoaks di media sosial meningkat sebesar $37,4 \%$. Hal yang sama juga ditunjukkan oleh Persamaan (2) yang mengindikasikan bahwa setiap peningkatan perkembangan berita hoaks di media sosial, maka perkembangan berita hoaks di media massa 
akan meningkat sebesar 37,4\%. Dengan kata lain, perkembangan berita hoaks di salah satu media tersebut saling mempengaruhi satu sama lain. Hal tersebut mengkonfirmasi hasil penelitian sebelumnya yang menunjukkan bahwa ada interaksi media sosial dan media massa dalam penyebaran suatu informasi (Azman, 2018).

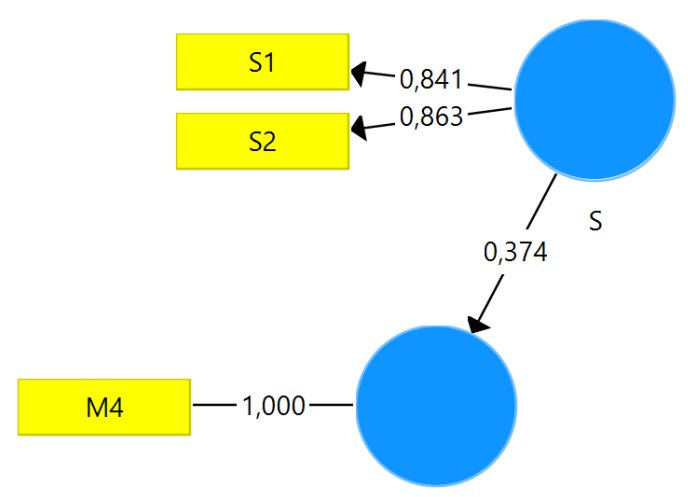

M

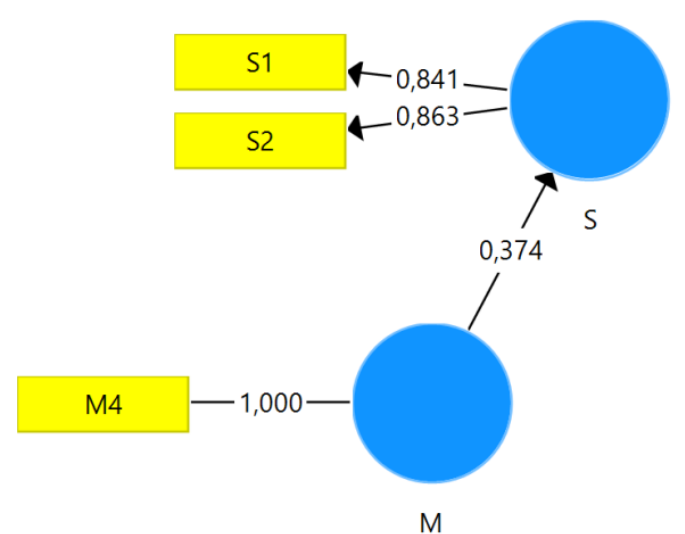

(a)

Gambar 5. Bentuk Akhir Model SEM-PLS untuk Perkembangan Berita Hoaks di

(a) Media Massa dan (b) Media Sosial

Pada umumnya, berita hoaks yang banyak tersebar di media sosial akan membentuk opini publik yang membuat berita tersebut tampak seperti benar (Juditha, 2018). Opini publik yang salah tersebut ikut berkembang di media massa. Kondisi ini dapat terjadi akibat kurangnya proses verifikasi dalam produksi berita di media massa maupun kualitas jurnalis yang kurang ideal (Fadli, 2018). Oleh sebab itu, perkembangan berita hoaks di media sosial akan turut mempengaruhi perkembangan berita hoaks di media massa. Sebaliknya, kesalahan pemberitaan di media massa juga mampu membentuk opini publik yang salah sehingga menimbulkan banyak informasi hoaks di media sosial. Untuk itu, upaya mengurangi perkembangan berita hoaks di Indonesia harus dilakukan secara bersama baik pada media sosial maupun media massa. Rekomendasi kebijakan berbasis hasil pemodelan struktural yang telah diperoleh guna mengatasi perkembangan berita hoaks di Indonesia tersebut disajikan pada Tabel 5. 
Tabel 5. Rekomendasi Kebijakan

\begin{tabular}{lll}
\hline \multicolumn{1}{c}{ Media Sosial } & \multicolumn{2}{c}{ Media Massa } \\
\hline $\begin{array}{l}\text { 1. Pemerintah dapat memblokir akun } \\
\text { - akun penyebar hoaks di media }\end{array}$ & $\begin{array}{l}\text { 1. Setiap kantor berita dapat } \\
\text { menerapkan seleksi dan verifikasi } \\
\text { berita secara ketat sebelum }\end{array}$ \\
sosial. & $\begin{array}{l}\text { dipublikasikan ke masyarakat. } \\
\text { 2. Pemerintah dapat memberikan }\end{array}$ \\
sanksi tegas bagi para pelaku dan & 2. Peningkatan kualitas jurnalis dan \\
penyebar berita hoaks di media & menegakkan kode etik jurnalistik. \\
sosial. & 3. Ikut memberantas berita hoaks \\
3. Pemerintah dapat aktif & yang berkembang di masyarakat \\
memberantas berita hoaks dengan & dengan memberikan klarifikasi \\
cara ikut memberikan klarifikasi & berita yang sebenarnya. \\
berita yang sebenarnya melalui & \\
akun - akun media sosial milik \\
pemerintah.
\end{tabular}

\section{SIMPULAN}

Secara umum, perkembangan berita hoaks di Indonesia banyak tersebar melalui media sosial dibandingkan media massa. Namun, perkembangan berita hoaks di salah satu media tersebut akan mempengaruhi peningkatan perkembangan berita hoaks di media lain secara signifikan. Dengan kata lain, perkembangan berita hoaks yang meningkat di media sosial akan menimbulkan peningkatan perkembangan berita hoaks di media massa, dan sebaliknya. Dalam hal ini, perkembangan berita hoaks di media sosial didominasi oleh media Whatsapp dan Facebook. Sebaliknya, perkembangan berita hoaks di media massa didominasi oleh media online. Untuk itu, diperlukan tindakan preventif dan represif secara bersama pada media sosial dan media massa guna mengatasi perkembangan berita hoaks di Indonesia seperti peningkatan proses verifikasi berita di media massa hingga tindakan tegas dari pemerintah berupa sanksi bagi pelaku dan penyebar berita hoaks di media sosial. Dengan demikian, perkembangan berita hoaks di kedua media tersebut dapat diminimalisir. Penelitian lebih lanjut dapat dilakukan dengan menambah variabel dan indikator 
lain untuk membuat pemodelan yang lebih kompleks dan menyeluruh terkait perkembangan berita hoaks di Indonesia.

\section{UCAPAN TERIMA KASIH}

Penulis mengucapkan terima kasih kepada Kementerian Pendidikan, Kebudayaan, Riset, dan Teknologi (Kemdikbud-Ristek) yang telah mendanai kegiatan penelitian ini melalui Program Kreativitas Mahasiswa (PKM) Tahun 2021 sehingga penelitian ini dapat dilaksanakan. Selain itu, penulis juga mengucapkan terima kasih kepada Fakultas Sains dan Teknologi, Universitas Airlangga yang mendukung pelaksanaan penelitian ini.

\section{DAFTAR PUSTAKA}

Agustina, D. (2018). Peleburan Realitas Nyata dan Maya: Hoax Menjadi Budaya Konsumtif Masyarakat Global. Jurnal Sosiologi Agama, 12(2), 245-260. https://doi.org/10.14421/jsa.2018.122-04

Asiati, D. I., \& Septadiyanto. (2018). Karakteristik Pengguna Media Sosial. Journal Management, Business, and Accounting, 17(3), 25-36. https://doi.org/10.33557/10.33557/mbia.v17i3.158

Avkiran, N. K., \& Ringle, C. M. (2018). Partial Least Squares Structural Equation Modeling: Recent Advances in Banking and Finance. Cham: Springer International Publisihng AG.

Azman. (2018). Penggunaan Media Massa dan Media Sosial di Kalangan Mahasiswa Komunikasi. Jurnal Peurawi: Media Kajian Komunikasi Islam, 1(1), 1-13.

Bungin, B. (2017). Politik Hiperreality dan Communicatioan Jammed. Dalam Buku Turn Back Hoax Tantangan Literasi Media Digital. Surabaya: Buku Litera dan Aspikom Korwil Jawa Timur.

Cahyono, E. F., Rani, L. N., \& Mardianto, M. F. F. (2021). Determinants of Indonesian Conventional and Islamic Bank Depositor Trust During the Covid-19 Pandemic. Journal of Islamic Monetary Economics and Finance, 7(1), 1-32. https://doi.org/10.21098/jimf.v7i1.1352

Fadli, A. (2018). Etika dan Tanggung Jawab Jurnalis (Studi Pemberitaan Hoax Melalui Media Online di Kota Makassar). Jurnalisa: Jurnal Jurusan Jurnalistik, 4(2), 181-195. https://doi.org/10.24252/jurnalisa.v4i2.6893

Ghozali, I. (2014). Structural Equation Modeling, Metode Alternatif dengan Partial Least Square (PLS). Edisi 4. Semarang: Badan Penerbit UNDIP

Hair Jr, J., Sarstedt, M., Ringle, C. M., \& Gudergan, S. P. (2017). Advances Issues in Partial Least Squares Structural Equation Modeling. Los Angeles: Sage Publications.

Juditha, C. (2018). Interaksi Komunikasi Hoax di Media Sosial serta Antisipasinya. Jurnal Pekommas, 3(1), 31-44. 
Kementerian Komunikasi dan Informasi. (2020). Hingga 10 Agustus Kominfo Tangani 1.082 Hoaks Covid-19 di Berbagai Platform. Diakses pada 27 Juni 2021, dari https://aptika.kominfo.go.id/2020/08/hingga-10-agustuskominfo-tangani-1-082-hoaks-covid-19-di-berbagai-platform/.

Kementerian Komunikasi dan Informasi. (2020). Kominfo Mencatat Sebanyak 1.028 Hoaks Tersebar Terkait Covid-19. Diakses pada 20 November 2020, dari https://kominfo.go.id/content/detail/28536/kominfo-mencatatsebanyak-1028-hoaks-tersebar-terkait-covid-19/0/sorotan_media.

Mardianto, M. F. F., Kartiko, S. H., \& Utami, H. (2019). Prediction The Number of Student in Indonesia who Study in Tutoring Agency and Their Motivations Based on Fourier Series Estimator and Structural Equation Modelling. International Journal of Innovation, Creativity, and Change, 5(3), 708-731.

Mardianto, M. F. F., Purwoko, C. F. F., Yudistira, I., Pathorrasyid, Kuziari, \& Faisol. (2021). Influence Factors about The Compliance of Madurese Community Related to Covid-19 Health Protocols Based on Structural Equation Modeling-Partial Least Square (SEM-PLS). Turkish Journal of Computer and Mathematics Education, 12(13), 3998-4006.

Mastel. (2019). Hasil Survey Wabah Hoax Nasional 2019. Diakses pada 24 Juni 2021, dari https://mastel.id/hasil-survey-wabah-hoax-nasional-2019/.

Putri, F.S. (2019). Pengaruh Faktor Personal dan Faktor Lingkungan Terhadap Intensitas Berbagi Melalui Sosial Media pada Komunitas Earth Hour Surabaya. Skripsi. Universitas Airlangga.

Rosmalinda, R. (2017). Fenomena Penyesatan Berita di Media Sosial dalam Artikel Ilmiah. Diakses pada 20 Mei 2021, dari http://www.seskoad.mil.id/admin/file/artikel/Artikel_Rury3.pdf.

Santosa, P. I. (2018). Metode Penelitian Kuantitatif Pengembangan Hipotesis dan Pengujiannya Menggunakan SmartPLS. Yogyakarta: ANDI.

The Asean Post. (2019). Between Fake News and Press Freedom. Diakses pada 04 Juni 2021, dari https://theaseanpost.com/article/between-fake-newsand-press-freedom.

Thompson, S. (2012). Sampling, 3rd Edition. New York: Wiley-Blackwell.

Wang, J., \& Wang, X. (2020). Structural Equation Modeling: Application Using Mplus, 2nd Edition. New Jearsey : Wiley. 